\title{
Identificação ideológica, partidos e voto na eleição presidencial de 2006
}

\author{
Yan de Souza Carreirão \\ Universidade Federal de Santa Catarina
}

\begin{abstract}
Resumo
O artigo analisa as relações entre a identificação ideológica do eleitor brasileiro, seus "sentimentos" em relação aos partidos e o voto nas eleições presidenciais de 2002 e 2006. A principal hipótese testada, a partir da análise dos dados das duas ondas do ESEB (Estudo Eleitoral Brasileiro), é a de que após o primeiro mandato do presidente Lula houve, na percepção dos eleitores brasileiros, uma diluição das diferenças ideológicas entre os partidos, o que redundaria em uma menor associação entre identificação ideológica e voto na eleição presidencial de 2006 comparativamente à de 2002. 0 artigo investiga também se houve mudanças na associação entre os "sentimentos partidários" dos eleitores e seu voto.
\end{abstract}

Palavras-chave: Estudo Eleitoral Brasileiro; eleições presidenciais; identificação ideológica; preferência partidária

\begin{abstract}
The article analyses the relations between the Brazilian voter's ideological identification, his/her "partisan feelings" and the vote, in the 2002 and 2006 presidential elections. The main hypothesis tested, which is based on the two waves of the ESEB (Brazilian Electoral Study) data analysis, is that after President Lula's first mandate there was a dilution of the ideological differences between the parties in the Brazilian voters view. This dilution would result in a smaller association between ideological identification and the vote in the 2006 presidential election compared to the 2002 election. The article also examines if there were changes in the association between the voters' "partisan feelings" and their vote.
\end{abstract}

Key Words: Brazilian Electoral Study; presidential elections; ideological identification; party preference 


\section{Introdução}

O presente artigo analisa a existência de relações entre a identificação ideológica do eleitor brasileiro, entendida como a auto-localização no contínuo direita-esquerda ${ }^{1}$, seus "sentimentos" em relação aos partidos e o voto na eleição presidencial de 2006.

Trabalhos anteriores testaram as hipóteses de que a identificação ideológica do eleitor está associada à sua preferência partidária e de que aquela identificação influencia seu voto, chegando a conclusões diferentes. De um lado, alguns autores apontaram o peso das variáveis ideológicas nas escolhas do eleitorado; de outro lado, autores questionaram a relevância de variáveis ideológicas sobre a decisão de voto como também o uso do auto-posicionamento na escala esquerda-direita como indicador da ideologia do eleitor. Há também divergências nas conclusões encontradas na literatura quanto ao tema das preferências e rejeições partidárias e sua relação com o voto. O aprofundamento da análise destes temas justifica, portanto, esta contribuição para o debate.

As hipóteses testadas aqui partem do pressuposto de que o primeiro mandato do presidente Lula representou um período de diluição das diferenças ideológicas entre os partidos, na percepção de boa parte do eleitorado brasileiro. As semelhanças entre o governo Lula e o governo de seu antecessor, o presidente Fernando Henrique Cardoso, em questões centrais, como a política econômica e reformas como a da Previdência, parecem ter contribuído para aquela diluição das diferenças. Da mesma forma, a percepção de que, também do ponto de vista ético, os partidos não apresentam comportamento tão diferenciado quanto se supunha parece ter reforçado esta percepção de diluição das diferenças entre partidos². Todas as gravíssimas denúncias de corrupção envolvendo personagens centrais do

\footnotetext{
1 A noção de identificação ideológica foi proposta por Singer (2000), que pleiteia, como apresento na revisão da literatura, que esta é uma das principais variáveis intervenientes na decisão de voto dos eleitores brasileiros. Aqui, as expressões "identificação ideológica", "posicionamento ideológico" e "posicionamento na escala esquerda-direita" são usadas, de forma intercambiável.

2 Embora o tema da corrupção não seja propriamente relacionado aos posicionamentos ideológicos dos partidos, até antes do primeiro mandato do presidente Lula parece ter havido uma percepção majoritária entre o eleitorado de que eram os partidos mais ao centro ou à direita do espectro ideológico os mais envolvidos em diferentes tipos de corrupção ou de desvios éticos. Em parte, essa percepção pode ter derivado do discurso fortemente moralista do PT até alguns anos atrás e em parte pode ser creditada ao fato de que os partidos de centro e direita, por terem controlado o governo federal e os principais governos estaduais, tiveram, até ali, mais acesso ao grosso dos recursos públicos (estando, portanto, efetivamente mais suscetíveis à corrupção). De toda forma, as diferenças percebidas entre partidos, a partir de seus discursos e/ou práticas no plano propriamente político-ideológico, eram reforçadas, ao que parece, por certa percepção de que partidos de esquerda (especialmente o PT) tinham um comportamento mais subordinado a preocupações éticas do que os partidos de centro e direita.
} 
PT e do governo ao longo do primeiro mandato do presidente Lula (tendo o "mensalão" como episódio central) podem ter contribuído - junto com a avaliação de que políticas centrais implementadas pelo governo Lula (e apoiadas pelos partidos da coalizão governista, inclusive o PT) não eram substancialmente diferentes das adotadas por seus antecessores - para uma percepção de diluição das diferenças entre os partidos de esquerda, de um lado, e de centro e direita, de outro. Esta diluição afetaria a relevância de variáveis ideológicas e partidárias no comportamento efetivo dos eleitores, incluindo sua decisão de voto.

Mais especificamente, uma hipótese testada neste artigo é a de que após o primeiro mandato do governo Lula ocorreu um declínio da porcentagem de eleitores que se auto-identificam ideologicamente e uma menor associação entre identificação ideológica e voto na eleição presidencial de 2006, comparativamente à encontrada na eleição de 2002. No que se refere às identificações partidárias, a hipótese é que também houve em 2006 uma menor associação entre os "sentimentos partidários" dos eleitores e o voto, mais uma vez de modo comparativo ao que ocorreu em 2002. Isso estaria vinculado àquela diluição das diferenças entre partidos, na percepção dos eleitores e, em particular, a um maior descolamento da imagem do presidente Lula em relação ao PT. Estas hipóteses são testadas tendo a escolaridade como variável de controle para verificar se eleitores com diferentes graus de escolaridade apresentam as mesmas associações entre voto e identificação ideológica e entre voto e "sentimentos partidários". A base empírica central é composta pelos dados do ESEB (Estudo Eleitoral Brasileiro) de 2002 e $2006^{3}$.

\footnotetext{
3 O ESEB 2002 foi uma pesquisa empreendida pelo DataUFF (sob a coordenação dos professores Alberto Carlos de Almeida e Zairo Cheibub) e pelo Centro de Estudos de Opinião Pública (Cesop / Unicamp) (sob a coordenação dos professores Rachel Meneguello e Fernando Lourenço), com o patrocínio da Capes e da Fapesp, envolvendo ainda muitas outras pessoas e instituições. O ESEB 2006 foi empreendido pelo Cesop e IPSOS. O trabalho de campo do ESEB 2002 foi realizado entre 31/10 e 28/12/2002, com a aplicação de questionário a uma amostra nacional de 2513 eleitores, com as seguintes características: amostra probabilística, sem reposição, em três estágios (município, setor censitário e domicílio). $O$ trabalho de campo do ESEB 2006 foi realizado entre 17 e 27/12/2006, envolvendo uma amostra nacional de 1000 eleitores em 70 municípios; amostra estratificada por regiões, com municípios maiores auto-representados e municípios menores sorteados; com seleção aleatória dos setores censitários e amostra por cotas (definidas de acordo com perfil de idade, escolaridade e PEA, cruzados por sexo) dentro dos setores censitários. Nos dois estudos, a margem de erro aproximada foi de $3,2 \%$.
} 
OPINIÃO PÚBLICA, Campinas, vol. 13, n 2, Novembro, 2007, p.307-339

\section{Revisão da literatura}

Trabalhos anteriores (SINGER, 2000; ALMEIDA, 2001; CARREIRÃO, 2002a) testaram a hipótese de que a identificação ideológica do eleitor está associada à sua preferência partidária e influencia seu voto, e chegaram a conclusões diferentes. Quanto às preferências e rejeições partidárias e suas relações com o voto, também houve divergências nas conclusões encontradas na literatura (KINZO, 1992; CASTRO, 1994; MENEGUELLO, 1995; SILVEIRA, 1998; SINGER, 2000; CARREIRÃO e KINZO, 2004; CARREIRÃO e BARBETTA, 2004; CARREIRÃO, 2007a e 2007b).

Foi Singer (2000) quem introduziu a noção de identificação partidária no debate brasileiro recente, definindo-a como "a adesão a uma posição no contínuo esquerda-direita ou liberal-conservador que, mesmo sendo difusa, isto é, cognitivamente desestruturada, sinaliza uma orientação política geral do eleitor" (SINGER, 2000, p.49). Com base em dados de surveys, utilizou a auto-localização dos eleitores no contínuo esquerda-direita para definir esta identificação. Para o autor, mesmo que a maioria dos eleitores não saiba definir o que seja esquerda e direita, pode utilizar estes conceitos para orientar sua decisão de voto porque se trata de um conhecimento intuitivo, um sentimento do que significam as posições ideológicas que permite ao eleitor situar os candidatos e os partidos nessa escala e votar coerentemente. Analisando dados de pesquisas de opinião realizadas entre as eleições de 1989 e 1994, postulou que a identificação ideológica seria uma predisposição de longo prazo e que teria sido um fator central da decisão de voto para presidente nestes dois pleitos. Do ponto de vista substantivo, a principal diferença de opinião entre os eleitores com identificação à esquerda e aqueles com identificação à direita está em que os primeiros esperam que sejam feitas mudanças a partir da mobilização social e da contestação da autoridade repressiva do Estado, enquanto o conservadorismo dos segundos se expressa no apego à autoridade e à ordem.

Carreirão (2002a), analisando dados de pesquisas realizadas entre 1989 e 1997, concluiu que a identificação ideológica parece ter certo peso na decisão de voto para presidente, mas não tão grande quanto postula Singer, já que outras variáveis revelaram ter maior influência na determinação dos resultados das eleições presidenciais. Além disso, a importância da identificação ideológica depende muito da escolaridade dos eleitores: à medida que esta aumenta, crescem linearmente: a) a compreensão dos termos "esquerda" e "direita"; b) o percentual de eleitores que se localizam numa escala "esquerda-direita" (ou seja, que se identificam ideologicamente) e c) o grau de associação entre esta identificação, de um lado, e o voto, a preferência partidária e as opiniões políticas dos eleitores, de outro. 
CARREIRAO, Y. S. Identificação ideológica, partidos e voto na eleição presidencial de 2006

Almeida (2001) questiona o próprio uso do auto-posicionamento dos eleitores na escala esquerda-direita como um indicador da ideologia: a maioria dos eleitores não sabe expressar o que é direita ou esquerda; os conteúdos atribuídos a estas expressões pela grande maioria dos eleitores são diferentes daqueles conteúdos atribuídos pela ciência política a estas noções. O autor conclui que é muito difícil medir o conceito de ideologia (relacionada ao espectro esquerdadireita) - e que a ciência política brasileira ainda não foi capaz de desenvolver uma boa medição deste conceito - e aposta mais em índices construídos a partir de baterias de questões sobre as visões de mundo das pessoas acerca de temas que permitam diferenciar entre esquerda e direita (por exemplo, opiniões sobre o grau de intervenção do Estado na economia; sobre o grau de apoio a soluções por meio de uma liderança forte; sobre o nível de apoio à igualdade, etc). Quanto ao peso da dimensão ideológica na decisão de voto, a partir de análises empíricas relativas a pesquisas realizadas no Rio de Janeiro na eleição para prefeito em 2000, o autor conclui que outras variáveis tiveram maior peso na explicação do voto do que a variável ideologia.

Como se vê, no que se refere ao uso do auto-posicionamento dos eleitores numa escala esquerda-direita, bem como no peso desta variável, ou outra que meça a dimensão ideológica, não há consenso na literatura.

Quanto às preferências partidárias, há também algumas variações nas avaliações feitas na literatura nacional sobre seu peso na decisão de voto. No que respeita ao período anterior ao governo Lula, um balanço sobre este debate (e sobre o debate teórico na literatura internacional) foi feito por Carreirão e Kinzo. Não é necessário replicar aqui aquele balanço, bastando, para as finalidades deste artigo, indicar que uma de suas principais conclusões foi que

\footnotetext{
"a rejeição partidária parece ter uma relação clara com o voto: em mais de $98 \%$ dos casos em que um eleitor manifestava rejeição a um partido, aquele não votava no candidato deste partido. Quanto à preferência partidária ... haveria por volta de 30\% de eleitores apenas, para quem a preferência partidária poderia ter influenciado o voto nas quatro eleições presidenciais até aqui realizadas. Tomando como base o único survey para o qual temos os dados relativos tanto à preferência quanto à rejeição partidárias, teríamos um contingente de cerca de $58 \%$ do eleitorado nacional para o qual os partidos não exerceriam influência sobre o voto e um contingente de cerca de $42 \%$ para o qual haveria uma potencial influência das avaliações feitas a respeito dos partidos, seja a partir de uma 'identificação' ou preferência, seja por uma rejeição a pelo menos um dos partidos." (CARREIRÃO e KINZO, 2004, p. 160-61)
} 
Artigos que enfocaram o tema dos partidos e sua relação com a decisão de voto no período recente foram Carreirão e Barbetta (2004), Carreirão (2007a e 2007b) e Venturi (2006). Nos dois primeiros, são feitas análises sobre a decisão de voto utilizando modelos logísticos contendo os "sentimentos partidários" como uma das variáveis. Ali se tentou sintetizar em uma só variável um conjunto de respostas dos eleitores a questões sobre "partido que representa o eleitor", "partido de que o eleitor gosta" e "partido em que o eleitor não votaria de jeito nenhum". Alguns problemas metodológicos limitam o alcance das conclusões destes estudos ${ }^{4}$, mas, de toda forma, há ali indícios significativos de que na eleição de 2002, pelo menos para os principais candidatos (Lula e Serra), as manifestações dos eleitores em relação aos partidos foram relevantes em suas decisões de voto.

O estudo de Venturi (2006) analisou as mudanças na percepção dos eleitores em relação ao PT após o episódio do "mensalão", mostrando que, comparativamente a uma pesquisa realizada pela Fundação Perseu Abramo em 1997, a imagem do PT piorou em alguns quesitos, como "partido que tem mais políticos que só pensam neles mesmos" e "partido que tem mais políticos corruptos". Mas melhorou nos quesitos "partido mais aberto à participação da população" e "que mais defende a justiça social", quesitos em relação aos quais está bem à frente dos demais partidos na visão do eleitorado.

Analisando dados relativos apenas às preferências partidárias, Carreirão (2007b) mostrou que a preferência pelo PT declinou razoavelmente durante o auge das denúncias do "mensalão" e recuperou-se ao longo de 2006, sem, porém, retomar os patamares anteriores àquele escândalo. Quanto à eleição presidencial de 2006, o autor concluiu que

“o voto segundo preferência partidária segue padrão semelhante ao das eleições anteriores: parcela majoritária dos eleitores (em torno de $60 \%$ ) não manifesta preferência por nenhum partido; entre os (cerca de 40\%) que manifestam, as associações com o voto são maiores entre eleitores do PT e do PSDB (além do PFL); entre os demais eleitores não há uma associação muito forte entre as variáveis." (CARREIRÃO, 2007b, p. 104)

\footnotetext{
${ }^{4}$ Os dois estudos utilizaram um modelo binomial de regressão logística para cada candidato, em vez de um único modelo polinomial (ver NICOLAU, 2007); além disso, a própria forma de operacionalizar as variáveis "sentimentos partidários" (para cada candidato) pode se ressentir do fato de que estas variáveis são definidas sem uma independência completa em relação à variável dependente (o voto em cada um dos candidatos).
} 
Finalmente, cabe assinalar que os estudos baseados em pesquisas de opinião que utilizam apenas a preferência partidária como indicador dos sentimentos partidários chegam à conclusão de que a influência dos partidos na decisão do voto é relativamente pequena; ao contrário, os poucos estudos que incluem várias questões encontram resultados mais positivos. Verificamos, adiante, se esta última tendência se manteve na última eleição presidencial, com base nos dados do ESEB $2006^{5}$.

\section{A identificação ideológica dos eleitores}

Os dados sobre o auto-posicionamento na escala "esquerda-direita" nas duas pesquisas mostram que o percentual de eleitores não-posicionados na escala (outras respostas: "não sabe"; "não respondeu"; "não sabe o que é esquerda e direita") passou de 23,2\% em 2002 para 41,8\% em 2006 (um aumento de 80\%). Este aumento se deu em detrimento especialmente dos eleitores que se posicionavam à esquerda da escala, que passaram de 25,7\% da amostra em 2002 para apenas 9\% em 2006. O dado relativo às "outras respostas" em 2006 (41,8\%) é muito relevante, pois significa que todas as análises a respeito da possível associação entre identificação ideológica e outras variáveis, como a preferência partidária ou o voto, só incluirão $58,2 \%$ do eleitorado (Tabela 1 ).

\footnotetext{
${ }^{5}$ Deve-se assinalar que algumas análises possíveis a partir do ESEB 2002 não são viáveis para o ESEB 2006, por esta última pesquisa ter aplicado um questionário bem mais reduzido em relação ao anterior; aí se incluem análises sobre a compreensão que os eleitores têm dos termos "esquerda" e "direita", bem como análises mais sólidas a respeito da eventual associação entre a identificação ideológica dos eleitores e suas opiniões políticas, já que o ESEB 2006 produziu um número bem menor de dados relativos às opiniões políticas dos eleitores a respeito de diferentes temas, comparativamente ao que havia feito o ESEB 2002. Especialmente em relação à compreensão que os eleitores têm dos termos "esquerda" e "direita" seria importante verificar se ainda havia em 2006 uma parcela significativa do eleitorado que em 2002 associou "esquerda" à oposição e "direita" ao governo. Se, em âmbito nacional havia até 2002 uma certa "adequação" destas "definições" aos fatos (já que os governos em âmbito federal haviam sido de centro-direita e a esquerda sempre havia ficado na oposição), a partir do governo Lula esta "adequação" deixa de ocorrer. Isto pode ter contribuído para "confundir" esta parcela do eleitorado, resultando no aumento das "outras respostas" à questão do posicionamento dos eleitores na escala esquerda-direita.
} 
OPINIÃO PÚBLICA, Campinas, vol. 13, n², Novembro, 2007, p.307-339

Tabela 1 - Identificação ideológica dos eleitores - 2002 e 2006

\begin{tabular}{|c|c|c|c|c|c|}
\hline \multirow{2}{*}{ ESEB } & \multicolumn{4}{|c|}{ Identificação ideológica } & \multirow{2}{*}{$\begin{array}{c}\text { Total } \\
\text { (N) }\end{array}$} \\
\cline { 2 - 5 } & Esquerda & Centro & Direita & $\begin{array}{c}\text { Outras } \\
\text { respostas * }\end{array}$ & 2513 \\
\hline 2002 & 25,7 & 23,3 & 27,8 & 23,2 & 2513 \\
\hline 2006 & 9,0 & 25,4 & 23,8 & 41,8 & 1000 \\
\hline
\end{tabular}

Fonte: ESEB, 2002 ( $N=2513)$ e ESEB, 2006 ( $N=1000)$.

* NS / NR / Não sabe o que é esquerda e direita.

Obs: As posições na escala de 0 a 10 foram assim agrupadas: esquerda: 0 a 3; centro: 4 a 6; direita: 7 a 10.

Em uma análise mais detalhada, as Tabelas 2 e 3 mostram os percentuais de eleitores com identificação ideológica segundo as faixas de escolaridade. Em 2002, à medida que aumentava a escolaridade, cresciam os percentuais de eleitores ao centro e à esquerda e declinavam os percentuais de eleitores à direita. Em 2006, a tendência relativa aos eleitores de centro e esquerda se manteve e, quanto aos eleitores que se identificam à direita, houve crescimento dos percentuais quando se passa da faixa de menor escolaridade até os eleitores com $2^{\circ}$ Grau, ocorrendo depois um declínio: o menor percentual de eleitores à direita ocorre entre aqueles com nível superior.

Tabela 2 - Identificação ideológica dos eleitores, segundo escolaridade - 2002 (\%)

\begin{tabular}{|c|c|c|c|c|c|}
\hline \multirow{2}{*}{$\begin{array}{c}\text { Identificação } \\
\text { ideológica }\end{array}$} & \multicolumn{4}{|c|}{ Escolaridade } & \multirow{2}{*}{$\begin{array}{c}\text { Total } \\
(\%)\end{array}$} \\
\cline { 2 - 5 } & $\begin{array}{c}\text { Até } 4^{\mathrm{a}} \text { série } \\
1^{\circ} \mathrm{Grau}\end{array}$ & $\begin{array}{c}5^{\mathrm{a}} \text { a } 8^{\mathrm{a}} \text { sér. } \\
1^{\circ} \mathrm{Grau}\end{array}$ & $2^{\circ} \mathrm{Grau}$ & Superior & 25,7 \\
\hline Esquerda & 19,8 & 24,8 & 28,6 & 35,3 & 23,3 \\
\hline Centro & 12,9 & 21,5 & 29,7 & 39,0 & 27,8 \\
\hline Direita & 31,6 & 29,6 & 25,0 & 21,4 & 23,2 \\
\hline Outras respostas* & 35,7 & 24,1 & 16,5 & 4,3 & 23,3 \\
\hline Total $(\mathrm{N})$ & $(867)$ & $(540)$ & $(783)$ & $(323)$ & $(2513)$ \\
\hline
\end{tabular}

Fonte: ESEB, $2002(\mathrm{~N}=2513)$.

* NS / NR / Não sabe o que é esquerda e direita.

Obs: As posições na escala de 0 a 10 foram assim agrupadas: esquerda: 0 a 3; centro: 4 a 6; direita: 7 a 10. 
CARREIRAO, Y. S. Identificação ideológica, partidos e voto na eleição presidencial de 2006

Tabela 3 - Identificação ideológica dos eleitores, segundo escolaridade - 2006 (\%)

\begin{tabular}{|c|c|c|c|c|c|}
\hline \multirow{2}{*}{$\begin{array}{c}\text { Identificação } \\
\text { ideológica }\end{array}$} & \multicolumn{4}{|c|}{ Escolaridade } & \multirow{2}{*}{$\begin{array}{c}\text { Total } \\
\text { (\%) }\end{array}$} \\
\cline { 2 - 5 } & $\begin{array}{c}\text { Analf./ Prim. } \\
\text { Compl. }\end{array}$ & Ginásio & Colégio & Superior & 9,0 \\
\hline Esquerda & 5,6 & 8,3 & 11,0 & 18,4 & 25,4 \\
\hline Centro & 21,2 & 25,7 & 28,4 & 32,0 & 23,7 \\
\hline Direita & 22,5 & 23,7 & 26,5 & 21,4 & 41,9 \\
\hline Outras respostas* & 50,8 & 42,3 & 34,1 & 28,2 & $(998)$ \\
\hline Total (N) & $(378)$ & $(253)$ & $(264)$ & $(103)$ & $(103)$ \\
\hline
\end{tabular}

Fonte: ESEB, $2006(\mathrm{~N}=1000)$.

* NS / NR / Não sabe o que é esquerda e direita.

Obs: As posições na escala de 0 a 10 foram assim agrupadas: esquerda: 0 a 3; centro: 4 a 6; direita: 7 a 10.

Um segundo aspecto a destacar é que o declínio da identificação à esquerda entre 2002 e 2006 se deu em todas as faixas de escolaridade. Por fim, mais relevante para nossos propósitos é o fato de que tanto em 2002 quanto em 2006 os percentuais de eleitores que não sabiam se localizar na escala (ou não responderam à questão) declinam continuamente, conforme aumenta o nível de escolaridade. Essa é uma tendência previsível e já encontrada em estudo anterior (CARREIRÃO, 2002a), mas é notável que o aumento dessas respostas entre 2002 e 2006 tenha se dado em todas as faixas de escolaridade, e que este aumento tenha sido maior quanto maior a escolaridade dos eleitores (entre os eleitores com nível de escolaridade superior, o salto foi espetacular, de 4,3\% para 28,2\%). Entre os eleitores com menor nível de escolaridade, a porcentagem dos que não sabiam se posicionar na escala ou não respondiam à questão em 2002 era 8,3 vezes a porcentagem entre os eleitores com nível superior em 2002 (35,7\% contra 4,3\%); em 2006 essa relação era apenas de 1,8 (50,8\% contra 28,2\%). Ou seja, houve uma espécie de "nivelamento" das porcentagens de eleitores que não se posicionavam na escala segundo a escolaridade. 
O posicionamento dos partidos (e de líderes) políticos na escala esquerda-direita, segundo a percepção dos eleitores

Um confronto entre o posicionamento ideológico dos partidos indicado pelos eleitores e a classificação mais usual entre os especialistas revela percentuais muito baixos de eleitores que realizam uma classificação "correta". Com exceção do PT, cujo posicionamento à esquerda é indicado por 45\% dos eleitores em 2002 e por $32 \%$ em 2006, para os demais partidos a taxa de "acerto" varia de $11 \%$ a $27 \%$ nos dois momentos (Tabelas 4 e 5). Mesmo considerando, de forma flexível, duas das três posições na escala como sendo "acertadas", só em relação ao PT o percentual de acerto passa de 50\% em 2002 (ver Tabela Anexa 1).

Tabela 4 - Posicionamento ideológico dos partidos (2002) (\%)

\begin{tabular}{|c|c|c|c|c|c|c|}
\hline \multirow{2}{*}{$\begin{array}{c}\text { Posicionamento } \\
\text { Ideológico }\end{array}$} & \multicolumn{6}{|c|}{ Partido } \\
\cline { 2 - 7 } & PT & PDT & PSDB & PMDB & PTB & PFL \\
\hline E & 45,4 & 27,3 & 14,2 & 14,9 & 20,7 & 14,0 \\
\hline C & 14,0 & 20,7 & 19,4 & 21,8 & 23,8 & 18,2 \\
\hline D & 17,9 & 12,3 & 34,2 & 34,6 & 16,8 & 34,8 \\
\hline $\begin{array}{c}\text { Outras } \\
\text { Respostas* }\end{array}$ & 22,8 & 39,8 & 32,2 & 28,6 & 38,8 & 32,9 \\
\hline
\end{tabular}

Fonte: ESEB, $2002(\mathrm{~N}=2513)$.

* NS / NR / Não conhece o partido / Não sabe o que é esquerda e direita.

Obs: As posições na escala de 0 a 10 foram assim agrupadas: esquerda: 0 a 3; centro: 4 a 6; direita: 7 a 10.

Tabela 5 - Posicionamento ideológico dos partidos (2006) (\%)

\begin{tabular}{|c|c|c|c|c|c|c|}
\hline \multirow{2}{*}{$\begin{array}{c}\text { Posicionamento } \\
\text { Ideológico }\end{array}$} & \multicolumn{6}{|c|}{ Partido } \\
\cline { 2 - 7 } & PT & PDT & PSDB & PMDB & PTB & PFL \\
\hline E & 31,7 & 21,9 & 13,3 & 10,8 & 16,9 & 14,2 \\
\hline C & 12,9 & 20,9 & 18,3 & 22,9 & 24,0 & 17,3 \\
\hline D & 15,9 & 10,1 & 24,3 & 21,5 & 11,0 & 22,3 \\
\hline $\begin{array}{c}\text { Outras } \\
\text { Respostas* }\end{array}$ & 39,6 & 47,1 & 44,4 & 44,8 & 48,1 & 46,2 \\
\hline
\end{tabular}

Fonte: ESEB, $2006(\mathrm{~N}=1000)$.

* NS / NR / Não conhece o partido / Não sabe o que é esquerda e direita.

Obs: As posições na escala de 0 a 10 foram assim agrupadas: esquerda: 0 a 3; centro: 4 a 6; direita: 7 a 10. 
Para cinco dos seis partidos, os posicionamentos mais freqüentes permanecem os mesmos entre 2002 e 2006: para o PDT, a maior porcentagem é de eleitores que o posicionam à esquerda, depois ao centro e, em menor proporção, à direita. $\mathrm{O}$ inverso ocorre com o PFL e o PSDB: a maioria relativa dos eleitores os posiciona à direita da escala. Note-se que não há, portanto, coincidência entre a classificação feita pelos eleitores e a classificação mais comum entre os especialistas, para quem o PSDB é classificado majoritariamente como de centro (ou de centro-direita). No que tange ao PTB, a maioria dos eleitores o posiciona ao centro; depois, um percentual menor o posiciona à esquerda e um percentual ainda menor à direita (contrariamente também à classificação mais usual do PTB como de direita ou centro-direita pela ciência política). Já no que se refere ao PT, embora tanto em 2002 como em 2006 a maior porcentagem seja a de eleitores que 0 situam à esquerda, a segunda maior porcentagem é dos que o situam à direita (e não ao centro, como, talvez, fosse o esperado). Por fim, em relação ao PMDB, houve uma variação nas posições relativas entre 2002 e 2006: em 2002, a maioria dos eleitores o classificava como de direita; a seguir, vinha o conjunto dos eleitores que o situavam ao centro. Em 2006, houve a inversão destes posicionamentos, permanecendo, porém, a menor porcentagem para os que o incluiam à esquerda do espectro ideológico.

Mais importante é a tendência entre 2002 e 2006 de perda de nitidez ideológica de vários partidos entre os eleitores: quanto ao PT, em 2002, o percentual de eleitores que o classificavam como de esquerda era 2,5 maior do que o percentual dos que 0 classificavam como direita; essa relação caiu para 2,0 em 2006. Com o PFL, a perda de nitidez ocorrida entre 2002 e 2006 foi ainda maior: o percentual de eleitores que o classificavam como de direita era 2,5 maior do que o percentual dos que o classificavam como de esquerda em 2002; essa relação caiu para 1,6 em 2006. Esta tendência pode ser generalizada para os demais partidos, embora em menor proporção ${ }^{6}$.

Porém, ainda mais importante para este estudo, são os percentuais bastante altos de eleitores que não conseguem classificar os partidos no contínuo esquerda-direita nos dois momentos. Em 2002, 32,5\% dos eleitores não conseguiam classificar os partidos; em 2006, este percentual aumentou para $45 \%$, em média.

A mesma tendência de perda de nitidez ideológica das imagens ocorreu em relação às lideranças políticas. Os questionários do ESEB de 2002 e 2006 solicitaram aos eleitores que situassem diversos líderes na escala esquerda-direita. Os únicos dois líderes apresentados simultaneamente aos entrevistados nos dois questionários foram Lula e Serra, sendo, portanto, os que permitem uma comparação direta para perceber tendências de mudança entre as duas eleições. Como se pode ver na Tabela Anexa 2,

\footnotetext{
${ }^{6}$ Outra forma de mostrar esta variação entre 2002 e 2006 é a partir dos diferenciais máximos entre os partidos: em 2002, havia 31,4\% a mais de eleitores que situavam o PT à esquerda em relação aos que situavam o PFL (à esquerda). Já em 2006, houve apenas 17,3\% a mais de eleitores que situaram o PT à esquerda em relação aos que situaram o PFL nesta posição da escala.
} 
também houve uma redução significativa da nitidez das classificações destes dois líderes naquela escala.

Até aqui a análise centrou-se em como os eleitores posicionam os partidos, os principais líderes políticos e a si próprios na escala esquerda-direita. Embora os "sentimentos partidários" dos eleitores, sua avaliação de desempenho do governo em exercício e seu voto não dependam apenas (nem principalmente) de sua identificação ideológica, em eleições anteriores observou-se certo grau de correlação entre esta última e aquelas outras variáveis (SINGER, 2000; CARREIRÃO, 2002b). A hipótese forte, pleiteada, por exemplo, por Singer (2000), é a de que a identificação ideológica é significativamente estável e influencia o comportamento dos eleitores ao avaliar partidos, governos e candidatos. As análises a seguir verificam em que medida há realmente associação entre estas variáveis e se houve variação no grau desta associação entre 2002 e 2006.

\section{Preferências e rejeições partidárias, segundo o posicionamento ideológico dos eleitores}

Os dados sobre a percepção dos eleitores quanto ao partido que melhor os representa não mostraram uma associação forte com a identificação ideológica. Para o PT, por exemplo, o maior percentual dos eleitores que afirmaram ser por ele representado se identificava à esquerda, mas o PT era também o partido que mais "representava" os eleitores, inclusive os "de centro" e os "de direita". Quanto aos demais partidos, os percentuais foram baixos e nem sempre corresponderam ao esperado, inclusive em razão das variações entre uma pesquisa e outra.

Tabela 6 - Partido que melhor representa o eleitor, segundo sua identificação ideológica 2002 (\%)

\begin{tabular}{|c|c|c|c|c|c|}
\hline \multirow{2}{*}{$\begin{array}{c}\text { Partido que melhor } \\
\text { representa o eleitor }\end{array}$} & \multicolumn{4}{|c|}{ Identificação Ideológica } & \multirow{2}{*}{ Total (\%) } \\
\cline { 2 - 5 } & Esquerda & Centro & Direita & $\begin{array}{c}\text { Outras } \\
\text { respostas* }\end{array}$ & 23,1 \\
\hline PT & 41,2 & 21,4 & 17,6 & 11,1 & 3,8 \\
\hline PMDB & 2,8 & 2,9 & 6,7 & 2,6 & 3,7 \\
\hline PSDB & 3,1 & 4,9 & 5,7 & 0,9 & 2,2 \\
\hline PFL & 2,6 & 1,7 & 3,3 & 0,9 & 2,3 \\
\hline Outros partidos & 2,8 & 2,7 & 2,3 & 1,5 & 64,7 \\
\hline Outras respostas * & 47,4 & 66,3 & 64,3 & 83,0 & $(2513)$ \\
\hline Total (N) & $(645)$ & $(587)$ & $(698)$ & $(583)$ & \\
\hline
\end{tabular}

Fonte: ESEB, $2002(\mathrm{~N}=2513)$.

ESEB31) Existe algum partido político que representa a maneira como o(a) $\operatorname{Sr}(a)$ pensa?

ESEB32) Qual o partido que melhor representa a maneira como o(a) Sr(a) pensa?

* Eleitores que responderam que nenhum partido os representa, não sabem, ou não responderam à pergunta 31; eleitores que indicaram partidos inexistentes, ou nome de políticos (e não de partidos), ou responderam que não sabem, não lembram, ou não responderam à questão 32. 
CARREIRAO, Y. S. Identificação ideológica, partidos e voto na eleição presidencial de 2006

Tabela 7 - Partido que melhor representa o eleitor, segundo sua identificação ideológica - 2006 (\%)

\begin{tabular}{|c|c|c|c|c|c|}
\hline \multirow{2}{*}{$\begin{array}{c}\text { Partido que melhor } \\
\text { representa o eleitor }\end{array}$} & \multicolumn{4}{|c|}{ Identificação Ideológica } & \multirow{2}{*}{ Total (\%) } \\
\cline { 2 - 5 } & Esquerda & Centro & Direita & $\begin{array}{c}\text { Outras } \\
\text { respostas* }\end{array}$ & 17,5 \\
\hline PT & 40,0 & 15,0 & 21,3 & 12,0 & 3,6 \\
\hline PMDB & 2,2 & 7,1 & 5,0 & 1,0 & 3,6 \\
\hline PSDB & 7,8 & 3,6 & 4,6 & 2,2 & 0,5 \\
\hline PFL & 0 & 0,4 & 0,8 & 0,5 & 2,2 \\
\hline Outros partidos & 6,6 & 2,4 & 4,2 & 0 & 72,6 \\
\hline Outras respostas * & 43,3 & 71,5 & 64,0 & 84,4 & $(1000)$ \\
\hline Total (N) & $(90)$ & $(253)$ & $(239)$ & $(418)$ & 3 \\
\hline
\end{tabular}

Fonte: ESEB, $2006(\mathrm{~N}=1000)$.

ESEB7) Existe algum partido político que representa a maneira como o(a) Sr(a) pensa?

ESEB8)Qual o partido que melhor representa a maneira como o(a) $\mathrm{Sr}($ a) pensa?

* Eleitores que responderam que nenhum partido os representa, não sabem, ou não responderam à pergunta 7; eleitores que indicaram partidos inexistentes, ou nome de políticos (e não de partidos), ou responderam que não sabem, não lembram, ou não responderam à questão 8.

As variações nas menções dos eleitores com diferentes identificações ideológicas quanto aos partidos que os representavam não foram, porém, grandes entre 2002 e 2006. Destaca-se apenas certo aumento das menções ao PT entre eleitores "de direita", concomitante a uma redução de menções ao partido por parte dos eleitores "de centro". Quanto ao PSDB, houve um pequeno aumento das menções entre os eleitores que se diziam de esquerda e, no que se refere ao PMDB, um pequeno crescimento entre os eleitores "de centro". Estas não foram, todavia, mudanças profundas no perfil ideológico dos eleitores que apontaram estes partidos como os que os representavam.

O mais relevante a assinalar é que houve um declínio do percentual dos eleitores que mencionavam algum partido em resposta à questão: em 2002, 35,3\% dos eleitores indicavam que algum partido os representava; este percentual caiu para $27,4 \%$ em 2006. Boa parte desta queda envolveu o PT, que continuou a ser o partido mais mencionado, mas caiu de $23,1 \%$ para $17,5 \%$ dos eleitores. Esta queda, certamente, está relacionada com as denúncias de corrupção envolvendo figuras centrais do partido, especialmente em 2005, no episódio do "mensalão". O PFL também declinou (de 2,2\% para 0,5\%), enquanto o PMDB e o PSDB mantiveram-se estáveis. Os demais partidos tiveram percentuais insignificantes para serem mencionados. 
OPINIÃO PÚBLICA, Campinas, vol. 13, n², Novembro, 2007, p.307-339

Com relação à rejeição partidária, em 2002 houve uma certa associação entre a identidade ideológica e a rejeição a partidos: a rejeição ao PT cresceu dos eleitores que se situaram à esquerda para os que se situaram à direita (o mesmo, mais ou menos, mostrou-se válido para o PDT); o inverso ocorreu para o PFL e o PMDB (e, mais ou menos, com o PSDB). Quanto ao PPB, não foi observado um sentido unívoco das rejeições. O mesmo ocorreu para o PTB, cuja imagem para muitos eleitores pareceu não corresponder à classificação mais freqüente na literatura de ciência política (conforme mostraram as Tabelas 4 e 5). De toda forma, as diferenças de percentuais de eleitores que rejeitam os partidos não foram muito grandes entre eleitores de posicionamentos ideológicos diferentes.

Em 2006, especialmente quanto aos partidos que só tiveram seus nomes incluídos nesta pesquisa, houve também certa associação: a rejeição a todos os partidos geralmente classificados como de esquerda foi maior entre os eleitores de direita. O inverso ocorreu para o PFL e o PSDB. Mas, as diferenças, novamente, não foram grandes e, para muitos partidos, não houve uma tendência unívoca de aumento das rejeições à medida que se passava dos eleitores de esquerda para os de direita (ou vice-versa).

Nas Tabelas 8 e 9, são apresentadas as rejeições aos partidos segundo o posicionamento ideológico dos eleitores. A soma de rejeições é sempre bastante superior a $100 \%$ e isso se deve ao fato de que os entrevistados podiam indicar mais de um partido como um dos que "não votaria de jeito nenhum", e muitos eleitores efetivamente indicaram mais de um partido.

Tabela 8 - Rejeição a partidos*, segundo identidade ideológica - 2002 (\%)

\begin{tabular}{|c|c|c|c|c|c|}
\hline \multirow{2}{*}{ Partidos } & \multicolumn{4}{|c|}{ Posicionamento Ideológico } & \multirow{2}{*}{ Total (\%) } \\
\cline { 2 - 5 } & Esquerda & Centro & Direita & $\begin{array}{c}\text { Outras } \\
\text { respostas* }\end{array}$ & T2,9 \\
\hline PT & 14,2 & 22,1 & 33,5 & 20,1 & 22,9 \\
\hline PFL & 57,6 & 43,4 & 42,7 & 39,4 & 46,1 \\
\hline PSDB & 43,3 & 32,7 & 34,2 & 33,0 & 36,0 \\
\hline PMDB & 43,7 & 33,1 & 29,2 & 33,5 & 34,9 \\
\hline PTB & 36,7 & 33,1 & 47,2 & 42,1 & 38,9 \\
\hline PDT & 38,5 & 36,9 & 53,3 & 38,4 & 40,8 \\
\hline PPB & 52,9 & 43,8 & 51,9 & 43,9 & 48,5 \\
\hline
\end{tabular}

Fonte: ESEB, 2002.

*Percentuais de eleitores que responderam "não votaria" à pergunta (P81): "Em qual destes partidos o(a) sr(a). não votaria de jeito nenhum" (estimulada e múltipla). As outras opções de resposta eram: "votaria", "não conhece o partido", NS/NR/NA. 
CARREIRAO, Y. S. Identificação ideológica, partidos e voto na eleição presidencial de 2006

Tabela 9 - Rejeição a partidos*, segundo identidade ideológica - 2006 (\%)

\begin{tabular}{|c|c|c|c|c|c|}
\hline \multirow{2}{*}{ Partidos } & \multicolumn{4}{|c|}{ Posicionamento Ideológico } & \multirow{2}{*}{ Total (\%) } \\
\cline { 2 - 5 } & Esquerda & Centro & Direita & $\begin{array}{c}\text { Outras } \\
\text { respostas* }\end{array}$ & \\
\hline PT & 28,9 & 24,9 & 31,8 & 24,2 & 26,6 \\
\hline PFL & 53,3 & 45,5 & 44,1 & 38,5 & 42,9 \\
\hline PSDB & 53,3 & 33,5 & 35,3 & 30,1 & 34,3 \\
\hline PMDB & 34,4 & 28,0 & 37,8 & 29,2 & 31,4 \\
\hline PTB & 47,8 & 41,5 & 48,7 & 33,5 & 40,4 \\
\hline PDT & 41,1 & 38,3 & 47,1 & 32,9 & 38,4 \\
\hline PCdoB & 42,9 & 42,7 & 53,8 & 38,5 & 43,6 \\
\hline PSOL & 44,4 & 36,2 & 55,6 & 36,1 & 41,6 \\
\hline PRONA & 61,1 & 49,8 & 58,8 & 40,8 & 49,2 \\
\hline PV & 38,9 & 39,0 & 53,6 & 33,4 & 40,1 \\
\hline PPS & 46,7 & 44,5 & 53,6 & 36,4 & 43,5 \\
\hline PL & 49,5 & 42,7 & 51,5 & 35,6 & 42,4 \\
\hline
\end{tabular}

Fonte: ESEB, 2006.

*Percentuais de eleitores que responderam "não votaria" à pergunta (P43): "Em qual destes partidos o(a) $\operatorname{sr}(a)$. não votaria de jeito nenhum" (estimulada e múltipla). As outras opções de resposta eram: "votaria", "não conhece o partido", NS/NR/NA.

Os seis primeiros partidos de cada tabela são os mesmos, permitindo comparações entre 2002 e 2006. No que se refere ao conjunto de eleitores (sem desagregar segundo identificação ideológica), houve poucas variações de uma eleição à outra quanto a estes seis partidos. O PT foi o partido que teve o maior aumento na taxa de rejeição (de 22,9\% em 2002 para 26,6\% em 2006), mas, ainda assim, continuou sendo o partido com a menor rejeição. Além disso, embora seja entre os eleitores "de esquerda" que o PT é o menos rejeitado, foi entre estes eleitores que sua rejeição mais aumentou (na realidade dobrou) entre 2002 e 2006. Além do PT, só o PTB teve uma pequena oscilação para cima na taxa de rejeição; PMDB, PSDB, PFL e PDT tiveram pequena redução nesta taxa.

Os demais partidos não apareceram como opção aos entrevistados nos dois momentos. O PPB só apareceu em 2002 e, naquela pesquisa, foi o partido mais rejeitado (48,5\% dos eleitores), seguido pelo PFL (46,1\%). Em 2006, o campeão foi o PRONA, com quase metade dos eleitores indicando rejeição ao partido.

\footnotetext{
7 É interessante observar que as taxas de "rejeição" a partidos de menor expressão são, na média, maiores do que as relativas aos maiores partidos, o que pode significar que o que é interpretado como "rejeição" pode ser, em parte, apenas uma manifestação de que o eleitor não votaria, não por conhecer o
} 


\section{Voto, avaliação de governo e posicionamento ideológico}

Quando analisamos as correlações entre os votos dos eleitores e seus posicionamentos ideológicos em 2002 e 2006, encontramos dados que sugerem o declínio da identificação ideológica. A Tabela 10 apresenta as correlações entre os votos dados pelos eleitores no $1^{\circ}$ turno das eleições presidenciais de 2002 e seus posicionamentos ideológicos. A Tabela 11 faz o mesmo para a eleição de $2006^{8}$.

Tabela 10 - Correlação: Voto $1^{\circ}$ turno x Posicionamento Ideológico, segundo Escolaridade - 2002

\begin{tabular}{|c|c|c|c|c|}
\hline \multirow{2}{*}{ Escolaridade } & \multicolumn{2}{|c|}{ Situação 1} & \multicolumn{2}{c|}{ Situação 2} \\
\cline { 2 - 5 } & $\begin{array}{c}\text { Coeficiente de } \\
\text { Correlação }\end{array}$ & Significância & $\begin{array}{c}\text { Coeficiente de } \\
\text { Correlação }\end{array}$ & Significância \\
\hline $\begin{array}{c}\text { Até } 4^{\text {a }} \text { série } \\
1^{\circ} \mathrm{Grau}\end{array}$ & 0,14 & 0,039 & 0,14 & 0,049 \\
\hline $\begin{array}{c}5^{\mathrm{a}} \text { a } 8^{\mathrm{a}} \text { série } \\
1^{\circ} \mathrm{Grau}\end{array}$ & 0,17 & 0,017 & 0,18 & 0,016 \\
\hline $2^{\circ} \mathrm{Grau}$ & 0,44 & 0,00 & 0,48 & 0,00 \\
\hline Superior & 0,43 & 0,00 & 0,45 & 0,00 \\
\hline Total & 0,29 & 0,00 & 0,30 & 0,00 \\
\hline
\end{tabular}

Fonte: ESEB, $2002(\mathrm{~N}=2.513)$

Situação 1 (da esquerda para direita): $1=$ Lula + Zé Maria; 2 = Ciro; $3=$ Garotinho; 4 = Serra

Situação 2 (da esquerda para direita): 1 = Lula + Zé Maria; 2 = Ciro + Garotinho; 3 = Serra.

Obs: Apenas 6 eleitores, na amostra, afirmaram ter votado em Zé Maria (tratar o candidato isoladamente, portanto, poderia levar a erros muito grandes).

partido e rejeitá-lo efetivamente, mas uma manifestação de que, não (re)conhecendo o partido, não votaria nele. Isso traz ambigüidade para a interpretação das respostas a esta questão.

8 São apresentadas, para cada eleição, correlações feitas com base em diferentes operacionalizações da variável voto (conforme observações abaixo das tabelas), já que pode não haver consenso sobre a ordenação dos candidatos numa escala esquerda-direita. As variações - tanto no coeficiente da correlação, quanto no nível de significância - devidas às diferentes maneiras de operacionalização das variáveis mostraram-se irrelevantes. Os dados que deram base ao cálculo destas correlações estão nas Tabelas Anexas 3 e 4. 
CARREIRAO, Y. S. Identificação ideológica, partidos e voto na eleição presidencial de 2006

Tabela 11 - Correlação: Voto $1^{\circ}$ turno x Posicionamento Ideológico, segundo Escolaridade - 2006

\begin{tabular}{|c|c|c|c|c|c|c|}
\hline \multirow{2}{*}{ Escolaridade } & \multicolumn{2}{|c|}{ Situação 1 } & \multicolumn{2}{c|}{ Situação 2 } & \multicolumn{2}{c|}{ Situação 3 } \\
\cline { 2 - 7 } & $\begin{array}{c}\text { Coef. de } \\
\text { Correl. }\end{array}$ & Signif. & $\begin{array}{c}\text { Coef. de } \\
\text { Correl. }\end{array}$ & Signif. & $\begin{array}{c}\text { Coef. de } \\
\text { Correl. }\end{array}$ & Signif. \\
\hline $\begin{array}{c}\text { Analf./ Prim. } \\
\text { Compl. }\end{array}$ & 0,15 & 0,368 & 0,08 & 0,639 & 0,15 & 0,368 \\
\hline Ginásio & 0,24 & 0,113 & 0,21 & 0,184 & 0,25 & 0,109 \\
\hline Colégio & 0,08 & 0,567 & 0,08 & 0,611 & 0,08 & 0,557 \\
\hline Superior & 0,43 & 0,004 & 0,47 & 0,002 & 0,43 & 0,008 \\
\hline Total & 0,17 & 0,022 & 0,14 & 0,088 & 0,18 & 0,021 \\
\hline
\end{tabular}

Fonte: ESEB $2006(\mathrm{~N}=1000)$..

Situação 1: 1 = Heloisa Helena; 2 = Lula; 3 = Cristovam Buarque; 4 = Alckmin.

Situação 2: 1 = Heloisa Helena + Lula; 2 = Cristovam Buarque; 3 = Alckmin.

Situação 3: 1 = Heloisa Helena; 2 = Lula + Cristovam Buarque; 3 = Alckmin.

Os dados das Tabelas 10 e 11 mostram que:

1) O coeficiente de correlação entre voto e identificação ideológica dos eleitores foi bem menor em 2006 (0,18, na melhor das hipóteses) do que em $2002(0,30)^{9}$. Além disso, a correlação em 2002 foi calculada sobre 64\% da amostra (os 1604 eleitores que simultaneamente apresentaram identificação ideológica e votaram em algum candidato). Em 2006, a correlação, além de ser menor, foi calculada apenas sobre os $50 \%$ da amostra que puderam ser incluídos no cálculo (já que a outra metade não manifestou identificação ideológica ou não votou em um dos candidatos). Assim, a associação entre as duas variáveis é bem mais fraca em 2006 do que em 2002;

2) A maior queda no coeficiente de correlação ocorreu entre eleitores com $2^{\circ} \mathrm{Grau}$ (Colégio): de 0,48 em 2002 para 0,08 em 2006. Por outro lado, entre eleitores com $5^{\mathrm{a}}$ a $8^{\mathrm{a}}$ série do $1^{\circ} \mathrm{Grau}$ (Ginásio), houve um pequeno crescimento dos coeficientes de correlação;

3) Apesar da diminuição do percentual de eleitores com nível superior com identificação ideológica entre 2002 e 2006, e considerando apenas os que mantiveram esta identificação, as correlações entre ela e o voto em 2006 tiveram magnitude e grau de significância semelhantes aos encontrados em 2002.

9 Davis (1976) classifica assim a força das correlações: até 0,09: associação desprezível entre as variáveis; 0,10 a 0,29: baixa; 0,30 a 0,49: moderada; 0,50 a 0,69: substancial; acima de 0,70: forte. 
A Tabela 12 apresenta, para as eleições de 2002 e 2006, as correlações entre a votação no segundo turno e o posicionamento ideológico dos eleitores segundo sua escolaridade ${ }^{10}$.

Os dados da Tabela 12 confirmam, mais uma vez, o declínio da associação entre o voto (agora para o $2^{\circ}$ turno) e a identificação ideológica dos eleitores: enquanto em 2002 a correlação foi de 0,40 e estatisticamente significativa, em 2006 foi de apenas 0,13 e estatisticamente não significante para o conjunto dos eleitores das amostras. Com exceção da $2^{a}$ faixa de escolaridade, nas demais houve um declínio significativo da correlação em pauta.

Tabela 12 - Correlação: Voto $2^{\circ}$ turno x Posicionamento Ideológico, segundo Escolaridade - 2002 e 2006.

\begin{tabular}{|c|c|c|c|c|}
\hline \multirow{2}{*}{ Escolaridade } & \multicolumn{2}{|c|}{2002} & \multicolumn{2}{c|}{2006} \\
\cline { 2 - 5 } & $\begin{array}{c}\text { Coefic. de } \\
\text { Correlação }\end{array}$ & Significância & $\begin{array}{c}\text { Coefic. de } \\
\text { Correlação }\end{array}$ & Significância \\
\hline $\begin{array}{c}\text { Até 4 } \text { série 1 }^{\circ} \text { Grau } \\
\text { (Até primário completo) }\end{array}$ & 0,24 & 0,004 & 0,10 & 0,572 \\
\hline $5^{\text {a }} \begin{array}{c}8^{\text {a }} \text { série 1 } \\
\text { (Ginásio) }\end{array}$ & 0,30 & 0,001 & 0,29 & 0,074 \\
\hline $2^{\circ}$ Grau (Colegial) & 0,51 & 0,000 & 0,10 & 0,498 \\
\hline Superior & 0,58 & 0,000 & 0,35 & 0,070 \\
\hline Total & 0,40 & 0,000 & 0,13 & 0,112 \\
\hline
\end{tabular}

Fonte: ESEB, 2002 e 2006.

Quanto aos dados de avaliação do governo, a comparação das duas pesquisas mostra que a associação entre a identificação ideológica dos eleitores e a avaliação que eles fazem do governo em exercício caiu de 0,21 em 2002 (estatisticamente significante) para 0,04 em 2006 (estatisticamente nãosignificante). Embora os coeficientes sejam relativamente baixos em 2002, foram estatisticamente significativos para quase todas as faixas de escolaridade (a exceção foi o coeficiente relativo ao nível superior de escolaridade). Em 2006, além de os coeficientes serem todos menores do que os de 2002, nenhum deles foi estatisticamente significativo ${ }^{11}$.

\footnotetext{
${ }^{10}$ Os dados que basearam o cálculo destas correlações são apresentados nas Tabelas Anexas 5 e 6.

11 Isso se deve, em parte, ao fato de a amostra ser bem menor em 2006. Mas deve-se também a uma menor associação entre as variáveis, o que é captado pela magnitude dos coeficientes. Os dados que basearam o cálculo destas correlações estão nas Tabelas Anexas 7 e 8.
} 
A queda do coeficiente de correlação foi especialmente grande entre os eleitores com nível de escolaridade superior. O fator que reforça ainda mais a tendência de declínio da associação entre as duas variáveis é o fato de o cálculo dos coeficientes ter como base $76 \%$ da amostra para 2002 e apenas 58\% da amostra em 2006.

Tabela 13 - Correlação entre Avaliação de Governo e Identidade Ideológica, segundo Escolaridade dos Eleitores - 2002 e 2006

\begin{tabular}{|c|c|c|c|c|}
\hline \multirow{2}{*}{ Escolaridade } & \multicolumn{2}{|c|}{2002} & \multicolumn{2}{|c|}{2006} \\
\hline & $\begin{array}{l}\text { Coeficiente } \\
\text { Correlação }\end{array}$ & Significância & $\begin{array}{l}\text { Coeficiente } \\
\text { Correlação }\end{array}$ & Significância \\
\hline $\begin{array}{l}\text { Até } 4^{\mathrm{a}} \text { série } 1^{\circ} \mathrm{Grau} \\
\text { (Até primário completo) }\end{array}$ & 0,12 & 0,050 & $\cdot 0,02$ & 0,882 \\
\hline $\begin{array}{c}5^{\mathrm{a}} \text { a } 8^{\mathrm{a}} \text { série } 1^{\circ} \text { Grau } \\
\text { (Ginásio) }\end{array}$ & 0,18 & 0,009 & 0,14 & 0,339 \\
\hline $2^{\circ}$ Grau (Colegial) & 0,18 & 0,001 & 0,01 & 0,978 \\
\hline Superior & 0,47 & 0,000 & 0,04 & 0,818 \\
\hline Total & 0,21 & 0,000 & 0,04 & 0,818 \\
\hline
\end{tabular}

Fonte: ESEB, 2002 e 2006.

Obs: As posições na escala de 0 a 10 foram assim agrupadas: esquerda: 0 a 3; centro: 4 a 6; direita: 7 a 10.

\section{"Sentimentos partidários" e voto}

A hipótese que foi testada quanto aos "sentimentos" expressos pelos eleitores em relação aos partidos é a de que em 2006 houve uma menor associação entre estes "sentimentos" e o voto para presidente comparativamente ao que ocorreu em 2002. Esta redução na associação entre as variáveis estaria vinculada àquela percepção da diluição das diferenças entre partidos e, em particular, a um maior descolamento da imagem do presidente Lula em relação ao PT.

A Tabela 14 apresenta a distribuição dos eleitores segundo os tipos de "sentimentos" que manifestavam em relação aos partidos em 2002 e $2006{ }^{12}$.

12 Quando um eleitor apontava um partido como aquele que representava a maneira como ele pensava, ou quando ele dizia "gostar" de um ou mais partidos, isso foi considerado um "sentimento positivo" em relação a este partido. Foi considerada um "sentimento negativo" a indicação de um partido à pergunta "em qual destes partidos o(a) sr(a). não votaria de jeito nenhum" (sendo que era lido o nome de cada um dos principais partidos e perguntado se o eleitor não votaria ou poderia votar). Muitos eleitores manifestaram, simultaneamente, sentimentos positivos em relação a um (ou mais) partido(s) e negativos em relação a outro(s) partido(s). Apenas em um número pequeno de casos, os eleitores manifestaram, 
OPINIÃO PÚBLICA, Campinas, vol. 13, n², Novembro, 2007, p.307-339

Tabela 14 - Distribuição dos eleitores, segundo seus "sentimentos partidários"* (em relação ao conjunto dos partidos) (2002/2006)

\begin{tabular}{|c|c|c|}
\hline SENTIMENTOS PARTIDÁRIOS & 2002 & 2006 \\
\hline Positivos e negativos & 43 & 30 \\
\hline Somente positivos & 7 & 7 \\
\hline Somente negativos & 35 & 40 \\
\hline Sem manifestação de sentimentos (positivos ou negativos) & 15 & 23 \\
\hline TOTAL (N) & $(2513)$ & $(1000)$ \\
\hline
\end{tabular}

Fonte: ESEB, 2002 e 2006. (Obs: as porcentagens foram "arredondadas").

* Sentimentos: Positivos = "partido que o representa" (espontânea e única) + "partido de que gosta" (espontânea e múltipla). Negativos = rejeição ["em quais destes partidos o(a) sr(a). não votaria de jeito nenhum"(estimulada e múltipla; pergunta feita para cada um dos partidos citados pelo entrevistador)]

Uma primeira observação é que os percentuais de eleitores que manifestaram algum tipo de "sentimento partidário" - e que, portanto, potencialmente poderiam levar em consideração estes "sentimentos" na sua decisão de voto - foram relativamente grandes: $85 \%$ (2002) e 77\% (2006). Estes percentuais são bem mais altos do que os percentuais de eleitores que manifestam preferência partidária nas pesquisas de opinião que utilizam apenas este tipo de pergunta a respeito da relação dos eleitores com os partidos. As porcentagens de eleitores que manifestavam rejeição a (pelo menos) algum partido foram maiores do que aquelas de eleitores que manifestavam sentimentos positivos.

Quanto às tendências de mudança entre 2002 e 2006, como os dados mencionados acima indicam, houve um aumento dos eleitores que não manifestaram qualquer "sentimento" por nenhum partido (de $15 \%$ para $23 \%$ no total). Isso se refletiu no declínio das porcentagens de eleitores que manifestaram tanto "sentimentos" positivos (50\% em 2002; $37 \%$ em 2006) quanto negativos (82\% em 2002; 70\% em 2006).

A análise a seguir verifica se estes "sentimentos" manifestados pelos eleitores em relação aos partidos estão ou não relacionados com seu voto. A Tabela 15 indica a votação em $1^{\circ}$ turno nos dois principais candidatos em 2002 e 2006, segundo seus "sentimentos" em relação ao PT e PSDB simultaneamente, partidos aos quais aqueles candidatos eram filiados ${ }^{13}$. Os "sentimentos" foram ordenados da situação teoricamente mais favorável ao candidato do PT (Lula) à situação mais favorável aos candidatos do PSDB (Serra e Alckmin).

simultaneamente, sentimentos positivos e negativos em relação a um mesmo partido. Estes casos não foram incluídos na tabela.

13 Uma análise mais completa precisaria incluir todos os sentimentos dos eleitores em relação a todos os partidos. Esta é uma tarefa importante a ser enfrentada, mas que não foi possível realizar aqui. 
CARREIRAO, Y. S. Identificação ideológica, partidos e voto na eleição presidencial de 2006

Tabela 15 - Voto em 2002 e 2006 ( $1^{\circ} \mathrm{t}$.), segundo sentimentos em relação ao PT e ao PSDB

\begin{tabular}{|c|c|c|c|c|c|c|c|c|c|}
\hline \multirow{2}{*}{ Ano } & \multirow{2}{*}{ Candidatos } & \multicolumn{7}{|c|}{ Sentimentos em relação ao PT e PSDB * } & \multirow{2}{*}{ Total } \\
\cline { 2 - 11 } & & 1 & 2 & 3 & 4 & 5 & 6 & 7 & \\
\hline \multirow{3}{*}{2002} & Lula & 88 & 81 & 64 & 41 & 7 & 23 & 1 & 51 \\
\cline { 2 - 11 } & Serra & 2 & 5 & 13 & 25 & 56 & 59 & 67 & 23 \\
\cline { 2 - 11 } & $(\mathrm{N})$ & $(315)$ & $(330)$ & $(260)$ & $(752)$ & $(259)$ & $(44)$ & $(70)$ & $(2030)$ \\
\hline \multirow{3}{*}{2006} & Lula & 97 & 95 & 95 & 62 & 13 & 53 & 7 & 67 \\
\cline { 2 - 11 } & Alckmin & 1 & 2 & 2 & 26 & 71 & 47 & 93 & 25 \\
\cline { 2 - 11 } & $(\mathrm{N})$ & $(117)$ & $(100)$ & $(111)$ & $(343)$ & $(120)$ & $(15)$ & $(28)$ & $(834)$ \\
\hline
\end{tabular}

Fonte: ESEB, 2002 e 2006.

* Sentimentos em relação ao PT e PSDB: 1 = sentimento positivo em relação ao PT e rejeição ao PSDB; 2 = somente sentimento positivo em relação ao PT; 3 = somente rejeição ao PSDB; $4=$ situações neutras $^{14} ; 5=$ somente rejeição ao PT; 6 = somente sentimento positivo em relação ao PSDB; $7=$ sentimento positivo em relação ao PSDB e rejeição ao PT. Quanto ao que foi considerado "sentimento positivo", ver observação abaixo da Tabela 14 .

Obs: Foram desconsiderados na análise os entrevistados que informaram não ter votado, ou que responderam que não se lembravam em quem haviam votado, ou cuja resposta foi "não sabe" ou "não respondeu" à pergunta sobre o voto no $1^{\circ}$ turno da eleição. As porcentagens foram calculadas sobre 0 total dos eleitores (em cada categoria de "sentimentos") que disseram ter votado em algum candidato, em branco ou nulo.

Os dados mostram uma fortíssima associação entre os "sentimentos" manifestados pelos eleitores em relação ao PT e ao PSDB e seu voto, tanto em 2002 quanto em 2006. Embora a tabela só mostre os dados para o $1^{\circ}$ turno de cada eleição, em relação à votação no $2^{\circ}$ turno as associações foram ainda maiores (coeficientes gama de 0,84 em 2002 e 0,91 em 2006). Há uma tendência claríssima de declínio do voto em Lula e crescimento do voto no candidato adversário (Serra em 2002 e Alckmin em 2006) à medida que se desloca da situação 1 - eleitores que gostam do PT ou dizem que este partido os representa e, simultaneamente, rejeitam o PSDB - para a situação 7 - eleitores que gostam do PSDB ou dizem que este partido os representa e, simultaneamente, rejeitam o PT. Enquanto entre os eleitores na primeira situação Lula venceria Serra e Alckmin por diferenças de $81 \%$ e 90\%, respectivamente, entre os eleitores na situação 7 a inversão é completa: Lula seria derrotado por Serra por 66\% de diferença em 2002 e seria derrotado por Alckmin por uma diferença de 73\% em 2006.

${ }^{14}$ Foram consideradas "situações neutras" aquelas em que o eleitor não manifestou nenhum sentimento em relação aos dois partidos, ou manifestou o mesmo sentimento (positivo ou negativo) em relação aos dois, ou manifestou sentimentos contraditórios (positivos e negativos, simultaneamente, a um mesmo partido). Poucos casos correspondem a esta última situação. 
A única inversão nas tendências de crescimento ou declínio contínuo nas votações dos candidatos, face ao aqui esperado em termos lógicos, ocorreu na passagem da posição 5 para a posição 6 , nas duas pesquisas. A princípio tomou-se como logicamente mais provável que um sentimento positivo em relação a um partido teria maior peso do que a rejeição a outro partido na decisão de voto. Assim, um eleitor que indicasse que gostava do partido A (ou que este partido representava mais suas idéias) teria maior chance de votar no candidato deste partido do que um eleitor que apenas rejeitasse o partido $B$, não manifestando sentimento positivo em relação a $A$. Esta suposição foi confirmada para o PT (especialmente em 2002), mas não para o PSDB. Os eleitores que em 2002 manifestavam apenas sentimento positivo pelo $\mathrm{PT}$, sem rejeição ao PSDB (posição 2) tinham maior chance de votar em Lula do que os eleitores que manifestavam apenas rejeição pelo PSDB, sem manifestar nada em relação ao PT (posição 3). Mas os eleitores que manifestavam apenas sentimento positivo pelo PSDB, sem rejeição ao PT (posição 6), em especial em 2006, tinham menor chance de votar em Alckmin do que os eleitores que manifestavam apenas rejeição pelo PT, sem manifestar nada em relação ao PSDB (posição 5) ${ }^{15}$. Assim, para a decisão de voto em Alckmin pesou mais a rejeição ao PT do que uma manifestação de apreço ao PSDB.

Um dado a ser destacado é que os eleitores que apenas rejeitavam o PSDB ou o PT, sem manifestação de apreço por nenhum dos dois partidos (ou seja, posições 3 e 5 da Tabela 15) representavam 26\% dos eleitores em 2002 e $28 \%$ em 2006. E entre estes eleitores a escolha foi claramente associada a esta rejeição: entre os eleitores que rejeitavam o PSDB, a vitória de Lula se dava por uma vantagem muito grande (bastante superior àquela encontrada na média do eleitorado) e o inverso ocorria entre os eleitores com rejeição ao PT: tanto Serra, em 2002, quanto Alckmin, em 2006, venciam Lula por boa margem entre estes eleitores.

Em 2006, o voto foi, aparentemente, um pouco mais associado aos "sentimentos partidários", já que as diferenças de voto (no sentido esperado) entre os candidatos foram maiores do que as encontradas em 2002, especialmente nas situações extremas do "sentimento partidário". Na realidade, isso se deve, em boa parte ao fato de a diferença entre Lula e Serra (de 28\%), em 2002, ser menor do que a diferença entre Lula e Alckmin (de 42\%) em 2006, para o conjunto do eleitorado. A razão disto é que, em 2002, outros candidatos (Garotinho e Ciro Gomes) tiveram boas votações, reduzindo as votações de Lula e Serra (e, portanto,

\footnotetext{
${ }^{15} \mathrm{Na}$ realidade, em 2002, aquela inversão apontada entre as posições 5 e 6 ocorreu apenas na votação de Lula. Em 2006, a inversão afetou a votação nos dois candidatos. Entre os eleitores que manifestavam apenas sentimentos positivos em relação ao PSDB (sem rejeição ao PT), Lula vencia Alckmin. O mesmo não aconteceu em 2002: Serra venceria Lula junto a estes eleitores.
} 
o diferencial entre eles), o que não aconteceu em 2006, quando Heloísa Helena e Cristóvam Buarque não conseguiram votações significativas. Calculando os percentuais de votos dados a cada um dos dois principais candidatos (Lula e Serra em 2002 e Lula e Alckmin em 2006) sobre o total de votos dados apenas aos dois, as diferenças de votação entre os candidatos passaram a ser muito semelhantes em 2002 e em 2006 em cada faixa de "sentimento partidário".

Por fim, cabe indicar que o percentual de eleitores que se situavam numa "situação neutra" em relação aos dois partidos foi de 41\% em 2002 (752 em 2030), enquanto representou 37\% dos entrevistados em 2006 (343 em 834).

\section{Considerações Finais}

Mostramos que o percentual de eleitores que não se posicionavam na escala ideológica passou de 23\% em 2002 para 42\% em 2006 (um aumento de 80\% em relação ao percentual de 2002). Este é o dado mais forte a apoiar a hipótese central deste artigo. Esta redução na identificação ideológica ocorreu, especialmente, em detrimento da esquerda, que passou de $26 \%$ do eleitorado em 2002 para apenas $9 \%$ em 2006. Além disso, a queda de identificação à esquerda se deu em todas as faixas de escolaridade.

As taxas de identificação ideológica são maiores conforme aumenta o nível de escolaridade, mantendo tendência já destacada na literatura, mas as disparidades entre as taxas de identificação ideológica das diferentes faixas de escolaridade reduziram entre 2002 e 2006.

O artigo mostrou também que os percentuais de eleitores que "acertaram" ao classificarem ideologicamente os partidos (tomando como referência a classificação mais freqüente entre os especialistas) foram muito baixos. Mesmo relaxando a exigência e aceitando duas das três posições (esquerda, centro ou direita) como "corretas", os percentuais de eleitores que "acertaram" foram baixos, o que se deve em boa parte aos altos percentuais de eleitores que não souberam localizar os partidos na escala. Estes últimos percentuais foram maiores em 2006 do que em 2002. Uma situação semelhante ocorreu para a localização de algumas das principais lideranças políticas na escala ideológica.

Esses dados sugerem que a grande maioria do eleitorado não posiciona os partidos e as lideranças políticas em uma escala esquerda-direita ou, quando o faz, não se aproxima da classificação mais comum entre os cientistas políticos. Uma parcela significativa dos eleitores também não posiciona a si própria na escala. Além disso, a proporção de eleitores que não conseguia se posicionar e não conseguia posicionar (ou posicionava "equivocadamente") partidos e lideranças na escala esquerda-direita foi maior em 2006 do que em 2002. 
Quanto à associação com outras variáveis, os dados não apontaram uma associação forte entre identificação ideológica e "sentimentos partidários" e não houve nenhuma mudança significativa nesta associação entre 2002 e 2006.

Para o conjunto do eleitorado, a correlação entre identificação ideológica e voto no $1^{\circ}$ turno foi moderada $(0,30)$ em 2002 e fraca $(0,17)$ em 2006. Neste último ano, apenas entre os eleitores com nível superior houve correlação de magnitude moderada, enquanto em 2002 isso havia ocorrido entre os eleitores com pelo menos $\circ 2^{\circ}$ Grau. Para o $2^{\circ}$ turno, a diferença entre as duas eleições foi ainda maior: correlação moderada (entre identificação ideológica e voto), de 0,40 em 2002 e fraca $(0,13)$ em 2006 . Enquanto nas faixas de $2^{\circ}$ Grau e nível superior as correlações em 2002 foram substanciais (0,51 e 0,58, respectivamente), em 2006 foram de magnitude bem menor $(0,10$ e 0,35 , respectivamente).

Da mesma forma, a associação entre a identificação ideológica dos eleitores e a avaliação que eles faziam do governo, que já era relativamente baixa em 2002 $(0,21)$, caiu para um valor quase nulo $(0,04)$ em 2006 (correlação estatisticamente não- significante).

É importante salientar ainda que a parcela do eleitorado que se autoposicionava ideologicamente foi menor em 2006 do que em 2002, o que amplifica as conclusões anteriores. Ou seja, mesmo para a parcela do eleitorado que se posicionava na escala (menor em 2006), as associações entre identificação ideológica e outras variáveis - como os "sentimentos partidários" do eleitor, a avaliação que este fazia do desempenho do governo e sua decisão de voto - foram menores em 2006 do que em 2002. Assim, no que se refere à identificação ideológica, se, em 2002, ela não parece ter sido uma dimensão tão importante, especialmente se os resultados aqui encontrados forem confrontados com as proposições de Singer (2000), em 2006 esta dimensão pareceu ainda menos relevante para entender outros aspectos do comportamento do eleitor. Os resultados parecem corroborar, portanto, a principal hipótese aqui formulada, de que após o primeiro mandato do presidente Lula houve, na percepção dos eleitores brasileiros, uma diluição das diferenças ideológicas entre os partidos, redundando numa menor associação entre identificação ideológica e voto na eleição presidencial de 2006 em comparação com a de 2002.

Quando analisamos a relação entre "sentimentos partidários" e voto, os resultados da análise indicaram, tanto para 2002 quanto para 2006, uma forte associação junto àqueles eleitores que percebiam diferenças significativas entre os partidos. Entre 2002 e 2006, o percentual dos eleitores para os quais não havia tanta diferença entre os partidos aumentou um pouco, seja por não terem manifestado nenhum sentimento em relação a partidos, seja por terem manifestado sentimentos semelhantes aos dois principais partidos. Mas isso não chegou a afetar a conclusão principal que afirma a associação. 
Com relação à influência dos partidos na decisão do voto, análises baseadas apenas em dados de preferência partidária têm chegado, em geral, à conclusão de que o contingente de eleitorado influenciado não é grande. No período entre $1989 \mathrm{e}$ 2002, em torno de $45 \%$ dos eleitores manifestavam preferência por algum partido, e pode-se supor que para cerca de dois terços destes (o que significa $30 \%$ do total do eleitorado) a preferência partidária pode ter influenciado o voto nas eleições presidenciais entre 1989 e 2002 (ver CARREIRÃO e KINZO, 2004). Porém, nos últimos anos, especialmente após a deflagração do episódio do "mensalão", o percentual médio de eleitores que têm manifestado preferência por partidos caiu para cerca de $40 \%$.

$\mathrm{Na}$ forma como as variáveis foram aqui operacionalizadas, o contingente do eleitorado para o qual havia um diferencial entre os partidos que poderia ser suficiente para afetar a decisão de voto (ou seja, todas as situações definidas na Tabela 15, com exceção das "situações neutras") variou entre 63\% (em 2002) e $59 \%$ (em 2006). Estes percentuais foram maiores do que os encontrados quando se utilizou a preferência partidária como o único indicador da possível influência dos partidos sobre a decisão de voto do eleitor. Além disso, a associação encontrada entre os sentimentos partidários e o voto foi forte, inclusive porque a rejeição a alguns partidos (que pode ser captada seja por pergunta do tipo "em que partido você não votaria de jeito nenhum?", seja por nota atribuída aos partidos) mostrou ter muita associação com o voto.

A discussão sobre o papel da ideologia na decisão de voto do eleitor abrange mais possibilidades do que as aqui investigadas, mas, especificamente no que se refere à idéia de que a dimensão ideológica pode ser captada através de posicionamentos no contínuo direita-esquerda, a idéia central é que os eleitores utilizam este contínuo para localizar a si mesmos, os partidos e os políticos, de forma a simplificar a compreensão do jogo político, economizando informação para a tomada de decisão. Dessa forma, boa parte dos eleitores votaria naqueles partidos ou políticos que mais se aproximariam de sua própria localização naquela dimensão. No caso brasileiro, Singer (2000) propõe que a identificação ideológica do eleitor (seu auto-posicionamento na escala esquerda-direita) teria sido uma das variáveis centrais na sua decisão de voto em 1989 e 1994. Vale notar que o maior coeficiente de correlação encontrado por aquele autor entre identificação ideológica e voto refere-se ao $2^{\circ}$ turno da eleição de 1989, momento em que houve a maior polarização ideológica entre candidatos de todo o período pós-redemocratização. Esta polarização ideológica, no entanto, segundo interpretação predominante na análise política nacional, foi se arrefecendo de 1989 em diante e este arrefecimento se acentuou bastante nos últimos anos. 
As evidências aqui apresentadas indicam que entre 2002 e 2006 houve um declínio da utilização, pelos eleitores brasileiros, da dimensão esquerda-direita para localizar a si mesmos, os partidos e os políticos e, a seguir, votar em conformidade com estes posicionamentos. Este declínio pode indicar que, na percepção de boa parte do eleitorado, após o primeiro mandato do presidente Lula ocorreu uma diluição das diferenças ideológicas entre partidos (e lideranças políticas), apontada no diagnóstico predominante na análise política brasileira. As semelhanças entre o governo Lula e o governo de seu antecessor, o presidente Fernando Henrique Cardoso, em questões centrais - como a política econômica e reformas como a da Previdência - e a formação de coalizões, abrangendo partidos ideologicamente bastante distantes (para não falar nas práticas utilizadas para manter estas coalizões), parecem ter contribuído para aquela diluição das diferenças. Mas, além destas mudanças ocorridas no comportamento dos partidos (especialmente no que concerne ao PT), o próprio fato de que parte dos eleitores associava "direita" a "governo" e "esquerda" à "oposição" (conforme mostram pesquisas anteriores, entre as quais o ESEB 2002) e de que esta "correspondência" tenha deixado de existir, no âmbito do governo federal, na gestão do presidente Lula, pode ter contribuído para "embaralhar" ainda mais o mapeamento do campo político, feito pelos eleitores, a partir das noções ideológicas. Segue daí que se a identificação ideológica dos eleitores teve certo poder analítico para o entendimento da decisão de voto em eleições presidenciais anteriores (em particular no $2^{\circ}$ turno da eleição de 1989), parece ter perdido boa parte deste poder. Embora possa haver alguma reversão - eventualmente com o crescimento de pequenos partidos de esquerda, como o PSOL e o PSTU, ou a criação de um partido assumidamente mais à direita -, a tendência mais provável, no curto prazo, é a de que o próprio contínuo esquerdadireita perca parte do poder analítico (e preditivo) como referencial para a compreensão do comportamento dos partidos e dos eleitores, comparativamente ao poder que teve até recentemente.

No que se refere às identificações partidárias, porém, não foi corroborada a hipótese de que também teria havido em 2006 uma menor associação entre os "sentimentos partidários" dos eleitores e o voto, comparativamente ao que ocorreu em 2002. A associação encontrada entre "sentimentos partidários" e voto em 2006 foi tão grande ou maior do que a encontrada em 2002.

Além de explorar um pouco mais esta conclusão, a análise a seguir tenta enfrentar a questão de como compatibilizar os dois achados: de um lado, o de que a dimensão esquerda-direita parece ter perdido parte de seu poder analítico e, de outro, o de que os sentimentos partidários mostraram-se associados à decisão de voto. Na realidade, parte relevante do eleitorado manifesta apreço ou rejeição por alguns partidos e estes sentimentos (para os que os manifestam) têm forte associação com seu voto. O PT continua sendo o partido em relação ao qual uma 
fatia maior do eleitorado manifesta sentimentos positivos; além disso, embora não seja o mais rejeitado, é o partido em relação ao qual a rejeição parece ter um impacto mais relevante na decisão de voto. O apreço ao PT talvez esteja associado à imagem de que é o partido que mais "defende os mais pobres", "defende a justiça social" (VENTURI, 2006). Talvez o que esteja ocorrendo é que parte dos eleitores diferencie os partidos a partir de certas imagens, mas estas seriam menos relacionadas à dimensão esquerda-direita do que a uma dimensão que diferencia os partidos segundo o grau em que estariam comprometidos com a defesa dos interesses dos mais pobres, do povo. Esta interpretação se aproximaria, em parte, da interpretação de Castro (1994):

(...) quando o sistema partidário e a filiação dos políticos aos partidos se mantiveram estáveis, o eleitorado popular das grandes cidades tendeu a fazer uma escolha consistente com sua situação social: optou, em maioria, pelo apoio a candidatos e partidos que pareciam estar mais próximos de seus interesses. Mais ainda (...) a escolha eleitoral estava relacionada com uma imagem sobre a posição dos partidos políticos, em termos dos interesses sociais por eles representados. É nos períodos que se seguem às grandes mudanças do sistema partidário que o voto popular parece ocasional, aleatório e diretamente determinado pela posição social e pelo grau de sofisticação dos eleitores (CASTRO, 1994, p.207).

A interpretação de Castro, como a anterior de Castro e Reis (1992), previa que, passado o período de grande mudança, na transição do bipartidarismo para o novo sistema partidário, tenderia a haver uma estabilização das identificações partidárias, já que perturbações circunstanciais nestas identificações, devidas a alterações na estrutura partidária não durariam "senão o tempo necessário para que se chegue novamente a divisar as linhas básicas de clivagem (...) nos novos contornos de cada estrutura implantada" (CASTRO e REIS, 1992, p. 131). E, neste novo contexto, qualquer partido que se pretenda popular precisaria "adquirir a imagem de partido 'dos pobres' - ou 'dos trabalhadores', desde que esta expressão seja tomada de maneira suficientemente difusa para tornar-se equivalente àquela" (idem, p.131).

Embora esta interpretação possa captar parte do que está ocorrendo, em particular a estruturação da imagem do PT como o partido que mais defende os mais pobres (substituindo o PMDB, que havia formado esta imagem perante uma parcela maior do eleitorado, pelo menos até boa parte da década de 80), alguns aspectos desta interpretação não parecem tão adequados à situação atual. Em 
primeiro lugar, não podemos falar, principalmente em 2006, apenas do "eleitorado popular das grandes cidades", já que o PT cresceu muito nas regiões mais pobres do país e, eventualmente, sua imagem como "defensor dos mais pobres" (associada em parte à imagem de Lula) pode ser mais forte em contextos muito distintos das grandes cidades. Em segundo lugar e mais importante, as "identificações partidárias" (se tomarmos as preferências partidárias como seu indicador) estão em declínio, ou seja, um percentual menor do eleitorado afirma hoje ter preferência por algum partido, comparativamente ao que ocorria há 20 anos. Diversos fenômenos concorrem para o declínio da importância dos partidos na estruturação do processo eleitoral, não só no Brasil, mas em âmbito internacional (ver CLARKE, H. \& STEWART, 1998; DALTON, R. J. \& WATTENBERG, 2000, entre outros), entre os quais - só para mencionar um aspecto importante no caso brasileiro e mencionado na citação de Castro - o enorme aumento da migração partidária no período recente (o que dificulta a formação de imagens partidárias duradouras). Por fim, a influência dos sentimentos partidários dos eleitores sobre seu voto não se dá só por identificação com determinado partido, mas também por rejeição a partido(s). Como foi visto, mais de um quarto dos eleitores em cada uma das eleições aqui analisadas manifestaram apenas rejeição a um dos dois principais partidos, sem nenhuma manifestação de apreço a algum deles. E, entre estes eleitores, a associação entre aquela rejeição e o voto é forte. Não é possível, porém, afirmar que a rejeição esteja associada a uma imagem dos partidos (rejeitados) como defensores dos interesses das "elites", ou dos "ricos" - o que reforçaria a tese de Castro e Reis quanto à dimensão principal que estaria envolvida na formação das imagens partidárias que têm certo grau de associação com a decisão de voto. Especialmente em relação ao PT, parece difícil imaginar que a rejeição esteja referida a tal tipo de imagem. É provável, por exemplo, que boa parte dos eleitores que manifestem tal rejeição seja composta daquele conjunto de eleitores que formou a imagem do PT como o "partido que tem mais políticos corruptos" (VENTURI, 2006). Mas, essa hipótese - assim como a de que são os eleitores que têm a imagem do PT como "partido defensor dos pobres" os que manifestam "sentimentos positivos" em relação a ele (gostam do partido ou acham que este os representa) - precisaria ser testada. Enfim, o que motiva os eleitores com diferentes níveis de sofisticação política a manifestarem "gosto" ou rejeição pelos partidos ainda precisa ser objeto de investigação mais aprofundada.

Em conclusão, enquanto a identificação ideológica dos eleitores mostrou baixo poder analítico para explicar o voto em 2006, os "sentimentos partidários" manifestados pelos eleitores revelaram-se associados de forma significativa ao voto. Considerando a força dessa associação, as conclusões encontradas aqui sugerem que vale a pena investir em formas mais sofisticadas de captar e analisar as manifestações de sentimentos dos eleitores em relação a partidos. Talvez ainda não tenhamos encontrado a melhor forma de operacionalizar questões para captar as manifestações de "sentimentos partidários" e, provavelmente, ainda não foram encontradas boas 
CARREIRAO, Y. S. Identificação ideológica, partidos e voto na eleição presidencial de 2006

formas de operacionalizar análises que levem em consideração todas estas manifestações.

Continuar em busca do aperfeiçoamento destes instrumentos de coleta e análise de dados relativos aos "sentimentos partidários" dos eleitores e às imagens que eles formam dos partidos, bem como das relações entre estas imagens e aqueles "sentimentos" e destes com o voto, é uma tarefa relevante para os pesquisadores do comportamento eleitoral no país.

Tabelas Anexas

Tabela Anexa 1 - Taxas de "acerto" dos eleitores ao posicionar os partidos na escala esquerda-direita (2002 / 2006)

\begin{tabular}{|c|c|c|c|c|c|c|c|}
\hline Critério & Ano & PT & PDT & PSDB & PMDB & PTB & PFL \\
\hline $\begin{array}{c}\text { Mais } \\
\text { exigente* }\end{array}$ & 2002 & 45 & 27 & 14 & 15 & 21 & 14 \\
\cline { 2 - 8 } & 2006 & 32 & 22 & 13 & 11 & 17 & 14 \\
\hline $\begin{array}{c}\text { Menos } \\
\text { exigente** }\end{array}$ & 2002 & 59 & 48 & 34 & 37 & 45 & 32 \\
\cline { 2 - 8 } & 2006 & 45 & 43 & 32 & 34 & 41 & 32 \\
\hline
\end{tabular}

Fontes: ESEB, 2002 e 2006.

* Critério mais exigente: PT e PDT = Esquerda; PSDB e PMDB = Centro; PTB e PFL = Direita;

** Critério menos exigente: PT e PDT = Esquerda ou Centro; PSDB e PMDB = Centro ou Direita; PTB e PFL = Direita ou Centro;

Tabela Anexa 2 - Posicionamento ideológico de lideranças políticas, segundo eleitores (2002) (\%)

\begin{tabular}{|c|c|c|c|c|}
\hline \multirow{2}{*}{$\begin{array}{c}\text { Posicionamento } \\
\text { ideológico }\end{array}$} & 2002 & 2006 & 2002 & 2006 \\
\cline { 2 - 5 } & Lula & Lula & Serra & José Serra \\
\hline Esquerda & 49,3 & 28,9 & 13,9 & 14,3 \\
\hline Centro & 11,4 & 12,4 & 17,5 & 17,0 \\
\hline Direita & 18,5 & 20,0 & 45,8 & 25,3 \\
\hline Não conhece & 0,2 & 0,8 & 0,3 & 2,7 \\
\hline Outras Respostas* & 20,7 & 37,7 & 22,6 & 40,6 \\
\hline
\end{tabular}

Fonte: ESEB, $2002(\mathrm{~N}=2513)$ e ESEB, 2006.

* NS / NR / Não sabe o que é esquerda e direita. 
OPINIÃO PÚBLICA, Campinas, vol. 13, n², Novembro, 2007, p.307-339

Obs: As posições na escala de 0 a 10 foram assim agrupadas: esquerda: 0 a 3; centro: 4 a 6; direita: 7 a 10.

Tabela Anexa 3 - Voto segundo posicionamento ideológico - $1^{\circ}$ turno 2002

\begin{tabular}{|c|c|c|c|c|c|}
\hline \multirow[b]{2}{*}{ Candidatos } & \multicolumn{4}{|c|}{ Posicionamento Ideológico } & \multirow[b]{2}{*}{ Total (\%) } \\
\hline & Esquerda & Centro & Direita & $\begin{array}{l}\text { Outras } \\
\text { resp.* }\end{array}$ & \\
\hline Zé Maria & 0,2 & 0,8 & 0,2 & 0 & 0,3 \\
\hline Lula & 66,1 & 42,5 & 41,2 & 50,3 & 50,2 \\
\hline Ciro & 7,5 & 11,5 & 11,2 & 6,0 & 9,2 \\
\hline Garotinho & 9,6 & 13,5 & 13,4 & 13,1 & 12,3 \\
\hline Serra & 12,5 & 25,6 & 28,5 & 22,3 & 22,2 \\
\hline Branco + Nulo & 2,0 & 3,7 & 2,3 & 3,6 & 2,9 \\
\hline Outras situações** & 2,1 & 2,4 & 3,2 & 4,6 & 3,0 \\
\hline Total $(\mathrm{N})$ & $(575)$ & $(520)$ & $(597)$ & (449) & $(2141)$ \\
\hline
\end{tabular}

Fonte: ESEB, 2002.

* NS / NR / Não sabe o que é esquerda e direita.

** Não votou, não lembra em quem votou, não sabe, não respondeu, não se aplica.

Tabela Anexa 4 - Voto segundo posicionamento ideológico - $1^{\circ}$ turno 2006

\begin{tabular}{|c|c|c|c|c|c|}
\hline \multirow[b]{2}{*}{ Candidatos } & \multicolumn{4}{|c|}{ Posicionamento Ideológico } & \multirow{2}{*}{$\begin{array}{c}\text { Total } \\
(\%)\end{array}$} \\
\hline & Esquerda & Centro & Direita & $\begin{array}{l}\text { Outras } \\
\text { resp.* }\end{array}$ & \\
\hline Heloísa Helena & 11,1 & 3,2 & 2,5 & 3,6 & 3,9 \\
\hline Lula & 60,0 & 55,7 & 52,9 & 56,0 & 55,6 \\
\hline Cristovam Buarque & 1,1 & 2,0 & 1,7 & 0 & 1,0 \\
\hline Alckmin & 17,8 & 25,7 & 26,1 & 16,0 & 21,0 \\
\hline Outras situações ${ }^{* *}$ & 10,0 & 13,4 & 16,8 & 24,4 & 18,5 \\
\hline Total $(\mathrm{N})$ & $(90)$ & $(253)$ & $(238)$ & $(418)$ & $(999)$ \\
\hline
\end{tabular}

Fonte: ESEB, 2006.

* NS / NR / Não sabe o que é esquerda e direita.

** Branco, nulo, não votou, não lembra em quem votou, não sabe, não respondeu, não se aplica. 
CARREIRAO, Y. S. Identificação ideológica, partidos e voto na eleição presidencial de 2006

Tabela Anexa 5 - Voto segundo posicionamento ideológico $-2^{\circ}$ turno 2002

\begin{tabular}{|c|c|c|c|c|c|}
\hline \multirow{2}{*}{ Candidatos } & \multicolumn{4}{|c|}{ Posicionamento Ideológico } & \multirow{2}{*}{ Total (\%) } \\
\cline { 2 - 5 } & Esquerda & Centro & Direita & $\begin{array}{c}\text { Outras } \\
\text { resp.* }\end{array}$ & \\
\hline Lula & 79,4 & 60,9 & 53,3 & 62,0 & 64,0 \\
\hline Serra & 16,1 & 32,5 & 39,8 & 28,2 & 29,2 \\
\hline Outras situações** & 4,5 & 6,6 & 7,0 & 9,8 & 6,8 \\
\hline Total (N) & $(573)$ & $(517)$ & $(595)$ & $(447)$ & $(2132)$ \\
\hline
\end{tabular}

Fonte: ESEB, 2002.

* NS / NR / Não sabe o que é esquerda e direita.

** Branco; nulo; não votou, não lembra em quem votou, não sabe, não respondeu, não se aplica.

Tabela Anexa 6 - Voto segundo posicionamento ideológico $-2^{\circ}$ turno 2006

\begin{tabular}{|c|c|c|c|c|c|}
\hline \multirow{2}{*}{ Candidatos } & \multicolumn{4}{|c|}{ Posicionamento Ideológico } & \multirow{2}{*}{ Total (\%) } \\
\cline { 2 - 5 } & Esquerda & Centro & Direita & $\begin{array}{c}\text { Outras } \\
\text { resp.* }\end{array}$ & \\
\hline Lula & 62,6 & 56,5 & 52,7 & 57,1 & 56,4 \\
\hline Alckmin & 23,1 & 25,7 & 30,0 & 17,3 & 22,9 \\
\hline Outras situações** & 14,3 & 17,8 & 17,3 & 25,7 & 20,6 \\
\hline Total (N) & $(91)$ & $(253)$ & $(237)$ & $(417)$ & $(1000)$ \\
\hline
\end{tabular}

Fonte: ESEB, 2006.

* NS / NR / Não sabe o que é esquerda e direita.

** Branco; nulo; não votou, não lembra em quem votou, não sabe, não respondeu, não se aplica.

Tabela Anexa 7 - Avaliação de governo segundo identidade ideológica dos eleitores (2002)

\begin{tabular}{|c|c|c|c|c|}
\hline \multirow{2}{*}{ Avaliação do governo } & \multicolumn{3}{|c|}{ Identidade Ideológica } & \multirow{2}{*}{ Total (\%) } \\
\cline { 2 - 5 } & Esquerda & Centro & Direita & \\
\hline Ruim / Péssimo & 54,5 & 46,4 & 38,0 & 46,1 \\
\hline Regular & 13,2 & 13,4 & 12,9 & 13,1 \\
\hline Otimo / Bom & 32,3 & 40,2 & 49,1 & 40,8 \\
\hline Total (N) & $(638)$ & $(584)$ & $(689)$ & $(1911)$ \\
\hline
\end{tabular}

Fonte: ESEB, $2002(\mathrm{~N}=2513)$.

Obs: 1) As posições na escala de 0 a 10 foram assim agrupadas: esquerda: 0 a 3; centro: 4 a 6; direita: 7 a 10. 
OPINIÃO PÚBLICA, Campinas, vol. 13, n², Novembro, 2007, p.307-339

2) Não foram aqui considerados os eleitores (602, ou seja, $24 \%$ do total) que não se posicionaram na escala ou não sabiam ou não responderam à pergunta sobre avaliação de governo.

Tabela Anexa 8 - Avaliação de governo segundo identidade ideológica dos eleitores (2006)

\begin{tabular}{|c|c|c|c|c|}
\hline \multirow{2}{*}{ Avaliação do governo } & \multicolumn{3}{|c|}{ Identidade Ideológica } & \multirow{2}{*}{ Total (\%) } \\
\cline { 2 - 4 } & Esquerda & Centro & Direita & \\
\hline Péssimo & 9,0 & 6,0 & 5,1 & 6,1 \\
\hline Ruim & 20,2 & 17,1 & 16,9 & 17,5 \\
\hline Bom & 53,9 & 67,3 & 70,3 & 66,5 \\
\hline Muito Bom & 16,9 & 9,6 & 7,6 & 9,9 \\
\hline Total (N) & $(89)$ & $(251)$ & $(236)$ & $(576)$ \\
\hline
\end{tabular}

Fonte: ESEB, $2006(\mathrm{~N}=1000)$.

Obs: 1)As posições na escala de 0 a 10 foram assim agrupadas: esquerda: 0 a 3; centro: 4 a 6; direita: 7 a 10.

2) Não foram aqui considerados os eleitores (424, ou seja, $42 \%$ do total) que não se posicionaram na escala ou não sabiam ou não responderam à pergunta sobre avaliação de governo.

\section{Referências Bibliográficas}

ALMEIDA, A. Ideologia e comportamento eleitoral: evidências de que a ideologia não é importante para explicar o voto. Paper apresentado ao XXV Encontro Anual da ANPOCS. Caxambu, 2001.

CARREIRÃO, Y. "Identificação ideológica e voto para presidente." Opinião Pública, vol.VIII, $\mathrm{n}^{\circ} .8$, p.54-79, 2002a.

A decisão de voto nas eleições presidenciais brasileiras. Rio de Janeiro/Florianópolis: Editora da FGV/EDUFSC, 2002b.

CARREIRÃO, Y. "Relevant factors for the voting decision in the 2002 presidential election: an analysis of the ESEB (Brazilian Electoral Study) Data". Brazilian Political Science Review, vol.1, $\mathrm{n}^{\circ} .1, \mathrm{p} .70 \cdot 101,2007 a$.

. "A eleição presidencial de 2006: uma análise preliminar." Política \& Sociedade, $\mathrm{n}^{\circ} .10, \mathrm{p} .91 \cdot 116,2007 \mathrm{~b}$. 
CARREIRÃO, Y. e KINZO, M.D.G. "Partidos políticos, preferência partidária e decisão eleitoral no Brasil (1989/2002)." Dados, vol.47, n.1, p.131-168, 2004.

CARREIRÃO, Y. e BARBETTA, P. "A eleição presidencial de 2002: a decisão de voto na região da Grande São Paulo." Revista Brasileira de Ciências Sociais, vol.56, p.75-93, 2004.

CASTRO, M. M. M. Determinantes do Comportamento Eleitoral. A Centralidade da Sofisticação Política. Tese de Doutorado, IUPERJ, Rio de Janeiro, 1994.

CLARKE, H. \& STEWART, M. "The Decline of Parties in the Minds of Citizens." Annual Review of Political Science, 1, p.357.378, 1998.

DALTON, R. J. \& WATTENBerg, M. (eds.). Parties Without Partisans. Political Changes in Advanced Industrial Democracies. Oxford: Oxford University Press, 2000.

DAVIS, J. Levantamentos de dados em sociologia: uma análise estatística elementar. Rio de Janeiro: Zahar, 1976.

KINZO, M. D. "A Eleição Presidencial de 1989: o Comportamento Eleitoral em uma Cidade Brasileira." Dados, vol.35, n.1, 1992.

MENEGUELLO, R. "Electoral Behavior in Brazil: the 1994 Presidential Election." International Social Science Journal, nº.146, 1995.

NICOLAU, J. "An analysis of the 2002 presidential elections using logistic regression." Brazilian Political Science Review, vol.1, nº.1, p.125-135, 2007.

REIS, F. W. e Castro, M. M. M. "Regiões, classe e ideologia no processo eleitoral brasileiro." Lua Nova, vol.26, p.81-131, 1992.

SILVEIRA, F. A decisão de voto no Brasil. Porto Alegre: EdipucRS, 1998.

SINGER. A. Esquerda e direita no eleitorado brasileiro. São Paulo: Edusp, 2000.

VENTURI, G. “A opinião pública diante da crise." Teoria e Debate, vol.66, 2006. 